\title{
Beta Cell Regeneration: A Novel Strategy for Treating Type 1 Diabetes
}

\section{Hao Wu${ }^{1}$ and Ram I Mahato ${ }^{1 *}$}

${ }^{1}$ Department of Pharmaceutical Sciences, University of Nebraska Medical Center, Omaha, NE 68198, USA

Type 1diabetes (T1D), which is typically caused by the autoimmune destruction of insulin-producing pancreatic islets, is affecting more than 1 million people in North America according to the National Diabetes Fact Sheet 2011. The key of treating T1D is to replenish the lost beta cells or their products, insulin. Insulin is commonly used for treating T1D. The occasional hypoglycemia post injection and the complications associated with long-term insulin administration may pose potential risks during a life-long insulin administration. Islet transplantation, as an experimental treatment for T1D, has the potential to maintain insulin-independence for a longer duration, but has failed to maintained normoglycemia for more than five years as per many studies $[1,2]$. During the last two decades, much effort has been made into exploring beta cell regeneration so that the new insulinproducing cells can replenish the lost beta cells caused by autoimmune destruction. Taking advantage of the progresses in protein sciences and regenerative medicine, beta cell regeneration may be promising for treating type 1diabetes in future.

It is commonly accepted that the total number of islets remains constant in the life time while the size of islet increases with age. Moreover, pancreatic beta cells which have longer life-span do not undergo proliferation frequently [3]. However, many preclinical studies revealed that given proper stimulation some beta cells may regain the potential to proliferate.Proliferation of beta cells is a dynamic process of which the intrinsic pathways have not been thoroughly understood. For example, though pancreatic beta cells which originated from the same ancestor showed no differences in gene expression profile. It was recently revealed that only a small group of specialized beta cells will regain the potential to proliferate under certain conditions [4].On the other hand, the majority of islets is replication-refractory beta cells which do not react to mitogenic stimulation [5].

Two categories of transcriptional factorsor hormones have been used to promote beta cell regeneration. The first category includes factors deeply involved in the development and differentiation of pancreatic beta cells. These factors include cyclin D1/D2, cyclindependent kinase 4 (CDK4), glucagon-like peptide-1 (GLP-1), Neurogenin 3 (Ngn3), pancreatic duodenal homeobox-1 (Pdx1) etc [6-9]. However, the molecular pathways bridging these factors were not thoroughly understood. Several factors such as CDK4, GLP-1 and Ngn3 were demonstrated to be effective to increase the mass of pancreatic beta cells in preclinical studies $[9,10]$.The second category includes other mitogenic factors such as vascular endothelial growth factor (VEGF) and hepatocyte growth factor (HGF). Although these factors were also proven to be helpful in preserving the beta cell mass in T1D animals $[11,12]$, they were absent from the intrinsic pathways governing the development and proliferation of pancreatic beta cells. Therefore, instead of working specifically on pancreatic beta cells, these factors seemed to work predominantly through combination with the native mechanism of beta cell regeneration in a synergistic or additive manner $[12,13]$.

Despite the progress in preclinical studies, two major obstacles need to be overcome to make a real clinical advance. The lack of beta cell specificity and the limited effect of these factors currently known to impact beta cell replication. Taken together, marginal effect of beta cell regeneration is expected if any of these factors are injected intravenously.
Luckily, the recent discovery made by Douglas Melton's group of Harvard University may shed some lights into this area [14]. This group developed a novel insulin resistance mouse model to induce pathologic beta cell replication which typically happened in an early stage of type 2 diabetes. Then, they identified betatrophin, a hormone produced by liver and fat, worked specifically on pancreatic beta cells to promote replication. Most importantly, they demonstrated that the injection of betatrophin expression plasmids via tail vein led to a 17 -fold increase in beta cell proliferationin just 8 days compared to the control.

Unlike previous factors, betatrophin showed both specificity and efficacy. Although the mechanisms underlying betatrophin induced beta cell proliferation is unclear, this study opens a new door to eliminate traditional insulin injection. It was reported that Evotec and Johnson \& Johnson who have the rights to the molecule planned to turn it into a preclinical type 2 diabetes candidate this year.

Stem cell-based regenerative medicine is another term frequently associated with the beta cell regeneration. Stem cells with proliferation capacity and transdifferentiation potential have been explored in depth to repair the bone defect and heart infarct $[15,16]$. It was lately discovered that the same mechanism of stem cells, especially bone marrow mesenchymal stem cells can be used to reverse hyperglycemia in T1D animals and promoted the beta cell regeneration [17]. The phenomenon can be explained by two distinct hypotheses: 1) stem cells produce soluble factors to promote the proliferation of preexisting beta cells and/or 2) stem cells can transdifferentiate to replenish the lost beta cells.

The first hypothesis is widely accepted since the gene expression profile of mesenchymal stem cells was revealed [18]. Mesenchymal stem cells produce two types of soluble factors with distinct functions. The immunosuppressive factors such as Prostaglandin E (PGE)-2 and Indoleamine 2, 3-dioxygenase (IDO) prevented the autoimmune destruction of beta cells by reversing the activation of hyper-reactive $T$ cells, while the trophic factors such as VEGF and HGF created an amiable environment for beta cell proliferation [19].

However, for the second hypothesis, it is still unclear whether stem cells can directly transdifferentiate to replenish lost beta cells in vivo. Although several groups have successfully transdifferentiated embryonic stem cells, adult stem cells and induced pluripotent stem cells into insulin-producing cells or even insulin-producing islet-like clusters in vitro, lineage tracing study provided limited support for this hypothesis in vivo [20-22]. Moreover, there are more practical challenges

*Corresponding author: Ram I. Mahato, $\mathrm{PhD}$ Department of Pharmaceutical Sciences University of Nebraska Medical Center, 986025. Nebraska Medical Center, Omaha, NE 68198-6025, USA, Tel: 402-559-5422; Fax: 402-559-9543 E-mail: ram.mahato@unmc.edu

Received September 30, 2013; Accepted October 01, 2013; Published October 04, 2013

Citation: Wu H, Mahato RI (2013) Beta Cell Regeneration: A Novel Strategy for Treating Type 1 Diabetes. Gene Technology 2: e106. doi: 10.4172/23296682.1000e106

Copyright: @ $2013 \mathrm{Wu} \mathrm{H}$, et al. This is an open-access article distributed under the terms of the Creative Commons Attribution License, which permits unrestricted use, distribution, and reproduction in any medium, provided the original author and source are credited. 
of pushing cell products through the pipeline, such as the lack of standard operational procedures among research groups, the possibility of bacterial and viral contamination, the risk of immunogenicity and tumorigenicity, and the significantly high cost of massive production.

To summarize, expanded knowledgeabout mechanisms of beta cell proliferation will create new methods to treat T1D.Betatrophin and stem cell therapy seems to be the two possible candidates on the way. For betatrophin, a star molecule to work specifically and potently on pancreatic beta cells, although its mechanism of action is unclear and more preclinical evidences are needed, it is leading the way to the first clinical trials in beta cell regeneration. On the other hand, stem cell therapy which is still under preclinical studies has faced more practical challenges. However, stem cell therapy has demonstrated its potential in many reports as a potent immunosuppressant and trophic mediator, which may provide useful insight to understand the onset of T1D and may prove as valuable assistantin beta cell regeneration. References

1. Ryan EA, Paty BW, Senior PA, Bigam D, Alfadhli E, et al. (2005) Five-year follow-up after clinical islet transplantation. Diabetes 54: 2060-2069.

2. Ryan EA, Shandro T, Green K, Paty BW, Senior PA, et al. (2004) Assessment of the severity of hypoglycemia and glycemic lability in type 1 diabetic subjects undergoing islet transplantation. Diabetes 53: 955-962.

3. Desgraz R, Herrera PL (2009) Pancreatic neurogenin 3-expressing cells are unipotent islet precursors. Development 136: 3567-3574

4. Smukler SR, Arntfield ME, Razavi R, Bikopoulos G, Karpowicz P, et al. (2011) The adult mouse and human pancreas contain rare multipotent stem cells that express insulin. Cell Stem Cell 8: 281-293.

5. Kushner JA (2013) The role of aging upon beta cell turnover. J Clin Invest 123 990-995.

6. Li Y, Cao X, Li LX, Brubaker PL, Edlund H, et al. (2005) beta-Cell Pdx1 expression is essential for the glucoregulatory, proliferative, and cytoprotective actions of glucagon-like peptide-1. Diabetes 54: 482-491.

7. Georgia S, Bhushan A (2004) Beta cell replication is the primary mechanism for maintaining postnatal beta cell mass. J Clin Invest 114: 963-968.

8. Rane SG, Dubus P, Mettus RV, Galbreath EJ, Boden G, et al. (1999) Loss of Cdk4 expression causes insulin-deficient diabetes and Cdk4 activation results in beta-islet cell hyperplasia. Nat Genet 22: 44-52.

9. Van de Casteele M, Leuckx G, Baeyens L, Cai Y, Yuchi Y, et al. (2013)
Neurogenin $3+$ cells contribute to beta-cell neogenesis and proliferation in injured adult mouse pancreas. Cell Death Dis 4: e523.

10. Lee JH, Jo J, Hardikar AA, Periwal V, Rane SG (2010) Cdk4 regulates recruitment of quiescent beta-cells and ductal epithelial progenitors to reconstitute beta-cell mass. PLoS One 5: e8653.

11. Lai Y, Schneider D, Kidszun A, Hauck-Schmalenberger I, Breier G, et al. (2005) Vascular endothelial growth factor increases functional beta-cell mass by improvement of angiogenesis of isolated human and murine pancreatic islets. Transplantation 79: 1530-1536.

12. Wu H, Yoon AR, Li F, Yun CO, Mahato RI (2011) RGD peptide-modified adenovirus expressing HGF and XIAP improves islet transplantation. J Gene Med.

13. Panakanti R, Mahato RI (2009) Bipartite vector encoding hVEGF and hIL-1Ra for ex vivo transduction into human islets. Mol Pharm 6: 274-284.

14. Yi P, Park JS, Melton DA (2013) Betatrophin: a hormone that controls pancreatic beta cell proliferation. Cell 153: 747-758

15. Grayson WL, Frohlich M, Yeager K, Bhumiratana S, Chan ME, et al. (2010) Engineering anatomically shaped human bone grafts. Proc Natl Acad Sci U S A 107: 3299-3304.

16. Orlic D, Kajstura J, Chimenti S, Limana F, Jakoniuk I, et al. (2001) Mobilized bone marrow cells repair the infarcted heart, improving function and survival. Proc Natl Acad Sci U S A 98: 10344-10349.

17. Ezquer FE, Ezquer ME, Parrau DB, Carpio D, Yanez AJ, et al. (2008) Systemic administration of multipotent mesenchymal stromal cells reverts hyperglycemia and prevents nephropathy in type 1 diabetic mice. Biol Blood Marrow Transplant 14: $631-640$.

18. Silva WA, Jr., Covas DT, Panepucci RA, Proto-Siqueira R, Siufi JL, et al. (2003) The profile of gene expression of human marrow mesenchymal stem cells. Stem Cells 21: 661-669.

19. Ryan JM, Barry FP, Murphy JM, Mahon BP (2005) Mesenchymal stem cells avoid allogeneic rejection. J Inflamm (Lond) 2: 8

20. Choi JB, Uchino H, Azuma K, Iwashita N, Tanaka Y, et al. (2003) Little evidence of transdifferentiation of bone marrow-derived cells into pancreatic beta cells. Diabetologia 46: 1366-1374.

21. Dor Y, Brown J, Martinez OI, Melton DA (2004) Adult pancreatic beta-cells are formed by self-duplication rather than stem-cell differentiation. Nature 429 : $41-46$.

22. Ramiya VK, Maraist M, Arfors KE, Schatz DA, Peck AB, et al. (2000) Reversal of insulin-dependent diabetes using islets generated in vitro from pancreatic stem cells. Nat Med 6: 278-282. 